https://doi.org/10.15407/socium2021.01.030

УДК 338.924

Omelyanenko V.A., PhD. (Economics), Associate Professor, Associate Professor of Business Economics and Administration Department, Sumy State Pedagogical University named after A.S. Makarenko, 72, Romenska Str., Sumy, 40002, Ukraine, email: omvitaliy@gmail.com, ORCID iD: http://orcid.org/0000-0003-0713-1444, Scopus Author ID: 56624321000, Researcher ID: Q-6358-2016

\title{
SOCIO-CULTURAL BASIS OF COMMUNITIES INNOVATION DEVELOPMENT: ARCHETYPICAL APPROACH ${ }^{1}$
}

Based on the analysis of modern theories and practical approaches to local development management, the author determined that many successful strategies for community revival are based on the ability of society and business to self-organize at the local level. The author identifies the formation factors of local innovation archetypes and the resource base of innovation development of communities. One of the main aspects of the formation of local innovation archetypes is the development of mechanisms for the public choice of the innovation process priorities and their implementation, and creating tools for broad information support and promotion of innovative ideas to create success stories. It is determined that the main tasks of local community development practices are capacity building and community empowerment, the transformation of local residents from actors into actors, development of participatory democracy and involvement of residents in the development of the territory (enhanced participation). The author substantiates that regional (local) innovation landscapes are more suitable for developing complex interactions and capital formation of ties as competitive advantages. The territories are communities of economic interest and can take advantage of ties and joint activities of economic entities. Implicit knowledge (cooperation between educational institutions, research institutions, business, staff relocation, public-private sector interaction, technology diffusion, etc.) in the measurement of networks depend heavily on coordination and are necessary for various innovations. Based on the analysis of local development theories, it is substantiated that the most effective tool developing of local communities is to involve people in joint activities aimed at achieving the public good or benefit for all participants. Examples of the best world experience and practices in involving communities in solving local development issues are considered.

Keywords: innovation archetype, communities, local development, development resources.

Омельяненко В.А., канд. екон. наук, доц., доцент кафедри бізнес-економіки та адміністрування, Сумський державний педагогічний університет імені А.С. Макаренка, вул. Роменська, 87, Суми, 40002, Украӥна, email: omvitaliy@gmail.com, ORCID iD: http://orcid.org/ 0000-0003-0713-1444, Scopus Author ID: 56624321000, Researcher ID: Q-6358-2016

\section{СОЦІОКУЛЬТУРНІ ОСНОВИ ІННОВАЦІЙНОГО РОЗВИТКУ ГРОМАД: АРХЕТИПНИЙ ПІДХІД}

За допомогою аналізу сучасних теорій і практичних підходів до управління місцевим розвитком визначено, щчо в основі ряду успішних стратегій відродження громад лежить здатність соиіуму й бізнесу до самоорганізаиії на локальному рівні. Виявлено фактори формування

\footnotetext{
${ }^{1}$ The publication was publicly funded by Ministry of Education and Science of Ukraine for developing of research project "Innovative component of security of sustainable development of old industrial regions of Ukraine: strategic directions of institutional support and technology transfer in innovation landscapes" and Project LET EDU 85399 / 17 (Italy).
}

(C) Omelyanenko V.A.,2021 


\begin{abstract}
локальних інновачійних архетипів і ресурсну базу інновачійного розвитку громад. Визначено, що одним з головних аспектів формування локальних інноваційних архетипів є розробка механізмів суспільного вибору пріоритетів інноваційного процесу та їх реалізації, а також створення інструментів інформаційної підтримки та популяризації інновачійних ідей для створення історій успіху. 3'ясовано, що головними завданнями, які ставлять перед собою практики розвитку місиевих спільнот, є нарощення здібностей населення (capacity building) ma наділення населення владою (соттипity етроwerment), перетворення місиевих жителів із суб'єктів впливу на суб'єктів дї, розвиток партисипативної демократії та залучення жстелів у розвиток території (enhanced participation). Обтрунтовано, щзо регіональні (локальні) інновачійні системи більш придатні для розвитку складних взаємодій і формування капіталу зв'язків як конкурентних переваг, оскільки саме території $\epsilon$ спільностями економічного інтересу та можуть скористатися перевагою зв'язків і спільної діяльності економічних суб' єктів, тобто створення неявного знання (співпраця між освітніми інституціями, науководослідними установами, бізнесом; переміщення персоналу; взаємодія між державним $i$ приватним сектором; дифузія технологій тощо) у вимірі мереж, що значною мірою залежать саме від координаційного управління та $\epsilon$ необхідними для різного роду інновацій. $3 а$ допомогою аналізу теорій місиевого розвитку обтрунтовано, щуо найефективнішим інструментом розвитку місиевих співтовариств є залучення людей у спільну діяльність, спрямовану на досягнення суспільного блага або користі для всіх учасників. Розглянуто приклади кращого світового досвіду і практик із залучення громад до розв'язання питань локального розвитку.
\end{abstract}

Ключові слова: інноваційний архетип, громади, місиевий розвиток, ресурси розвитку.

The development of communities on an innovation basis and the construction of appropriate economic activity require the mobilization of efforts of all social structures, involvement in the learning process of all segments of society, recognition of the unique role of education and science not only for high-tech industries but also for the traditional economy and daily life. We believe that the aspect of innovation development plays a dual role and in contrast to the traditional approach, which is often used in the development of territories, when the competitive advantages of traditional nature (for example, for tourists) allows both to improve the quality of life and create conditions community development and relevant territory. The urgency of developing local development strategies is because a significant part of the population of Ukraine lives in the so-called depressed regions and has insufficient opportunities for development. In 2019, in 20 regions where $74 \%$ of the country's population or 31,4 million people live, the GRP rate per person was lower than the average in Ukraine ${ }^{2}$. The crisis of 2020 has shown the urgent need to change the regulatory system in the direction of creating a system of public-state partnership. Therefore, managing the development of the territory is to form and support the mechanism of self-organization of society, which people launch, works with people's help, and allows to obtain a concrete result of the development of the territory taking into account local interests.

\footnotetext{
${ }^{2}$ The Ministry of Regional Development discussed the draft Concept and the plan for the implementation of state regional policy. Ministry of Development of Communities and Territories of Ukraine. (2020, February 14). URL: https://www.minregion.gov.ua/press/news/u-minregioni-obgovorili-proektkontseptsiyi-ta-plan-realizatsiyi-derzhavnoyi-regionalnoyi-politiki/ [in Ukrainian]
} 
Economic, sociological, political science studies show that communities based on trust and cooperation contribute to realising human potential. The fact that social ties and trust play an important role in supporting economic development is increasingly noted in economic literature. Some authors consider the factor of social capital as a necessary term for such aspects of society that, despite the complexity of measurement and inclusion in formal models, are considered the most critical determinants of long-term economic success [1]. The realization that "society matters" forces economists to consider this factor even when constructing theoretical hypotheses. According to Pantem, "Social capital, embodied in the norms and networks of social participation, is a prerequisite for economic prosperity, as well as effective self-government". In economic theory, the term "social capital" is used mainly as a type of capital as a tool to use the economic principles of rational behaviour in the analysis of social systems. From an economic point of view, it is vital that social capital as a special resource complements and can replace other economic resources, leading to reduced production and transaction costs. Social goals are much broader than sustainable economic growth because, firstly, aggregate rather than economic well-being is essential. Secondly, the analysis of policy options must also include long-term effects on economic, environmental and environmental factors and social trends [2]. According to the concept of human qualities, the development of society and the economy through technological improvement is closely linked to the quality of the workforce. The concept of relevant technologies is closely linked to the concept of human qualities. If the qualities of the endogenous population can affect the acceptability of various forms of industrial development for the territory, then taking into account these qualities is an essential condition for successful modernization in a particular social and cultural environment. In the study of Hall and Jones [3], the main factor of efficiency, which forms the leading cause of differences in the world level of economic development, is considered to be social infrastructure. Researchers propose to consider this category as a state and institutional policy that shapes the economic environment. To increase production efficiency, we need a social infrastructure that would increase production activity, capital accumulation and the introduction of technology.

Bruno argues that the history of non-urban areas of Quebec (Canada) illustrates the creativity and ingenuity of the inhabitants (thesis "small towns - big ideas") [4]. Weber [5] analyzing the relationship between globalization and rural development, among the many regional economic impacts of globalization on rural areas - outsourcing, tourism development, integration of agricultural markets into world trade, declining local supply of villages and small towns and services, notes that the function of innovation, in particular the development of innovation centres, is a very problematic aspect. As a result, today in Europe, the network of small towns includes modern industrial and tourist centres. In the United States, university campuses are scattered throughout the country. Simon [6], a well-known German scientist notes in "Hidden Champions" that rural areas and small towns have become home to world-class companies, leaders in highly specialized markets: the vast majority of "hidden champions", who are innovation leaders, works in small towns. The authors on the example of EU countries explain the differentiation of countries by institutional, infrastructural and economic conditions of innovation (models of technological 
specialization, the intensity of investment in innovation, the structure of national innovation system, the structure of business costs for innovation, the openness of national innovation systems) is the peculiarities of development at the regional level. Thus, the formation of regional innovation landscapes is an important task that can create a basis for development and economic and long-term social investment.

This work aims to analyse the socio-cultural features of the involvement of the community of small towns in the innovation landscape development based on the analysis of world practice and guidelines for policy implementation in Ukraine.

Modern regional policy is implemented based on targeting specific problems and implementing infrastructure projects. In foreign countries, new approaches are used to stimulate regional development through measures aimed at maximizing regional capacity, promoting entrepreneurship and innovation, supporting educational projects and retraining the local workforce, which allows better use of the potential of depressed regions in connection with the development of more prosperous regions of the country.

In developed countries, identifying the linkages between the formation (and/ or strengthening) of local communities, people's ability to self-organize and quality of life has become an important basis for the spread in the second half of XX century local community development issues. Thus, the establishment of a double correlation between the level of development of the local community and the ability of society and business to self-organize at the local level, and between the ability of society and business to self-organize at the local level and quality of life formed the basis of some successful community revitalization strategies.

Local innovation landscapes are more suitable for the development of complex interactions and capital formation of ties as competitive advantages because the territories are communities of economic interest and can take advantage of ties and joint activities of economic entities, i.e. the creation of implicit knowledge (cooperation between educational institutions, research institutions, business, staff relocation, public-private sector interaction, technology diffusion, etc.) in the dimension of networks that depend heavily on coordination management and are necessary for various kinds of innovation.

The importance of small towns is growing in the transition from industrial to a post-industrial society, due to the key role of the following factors contributing to the phenomenon of ruralisation: simplification of migration, communication and exchange of information over long distances, increasing the number of specialities remote (smart education).

At the beginning of the $21^{\text {st }}$ century, the development of small towns is gaining new importance, but this problem has been quite relevant for many countries for a long time. For example, in the 40's of the twentieth century in Great Britain, a plan was developed to build "new cities" that would be free of the environmental and social problems of the "old". This idea has been picked up in many countries. Already in the 1970s, also beginning with the United States, the process of counter-urbanization was manifested in the industrialized countries, which was expressed in the return influx of population from large cities to small towns in the countryside. 
Despite this, developed innovation economies are based on local innovations. In the EU, the percentage of science and technology parks operating in small towns exceeds $50 \%$. In Central Europe, this figure is even higher, which is logical, as it is a region with high urban density. However, in Eastern Europe, in particular Ukraine, most science parks are located in large cities, although the density of cities in this area is lower.

The dependence of competitive advantages on the local conditions of a particular territory was analysed by the apologist of the concept of competitiveness M. Porter, who notes that competitive advantage is created and maintained in close connection with local conditions, i.e. activation of this specific regional potential should become the basis for development. The growing interest of economists in the concept of small town's development is based on a large number of convincing facts that the most important components of the innovation process (innovation generation, technology transfer, etc.) are geographically localized. M. Porter noted that the stable competitive advantages of firms at the global level are often provided by their strong positions "on the ground": the concentration of highly specialized industries, personnel, institutional structures, suppliers, etc., in specific regions.

Based on this, the local innovation archetype can be defined as a factor determining the approach to innovation, the inherent innovation strategy and the most typical ways to implement this strategy. According to the approach, the innovation archetype defines:

- organizational format of innovation development, which is the most natural and productive (most often the choice between self-generation, transfer from the scientific sphere, copying or modification of existing technologies);

- sources and methods of searching and collecting information;

- internal mechanisms for innovation;

- priority approaches in finding innovations.

The development of innovation development strategies concerning local development is carried out mainly within the framework of economics. In determining the principles of innovation, development should be noted the presence of qualitative changes in various spheres of society through the development, creation and effective use of innovations (economic, social, institutional and environmental) to increase social welfare. However, in previous studies [7-9], based on neo-institutional methodology, the context of the problems of innovation development should be expanded, especially considering the socio-cultural basis of the local innovation archetype.

One of the main aspects of local development is the development of mechanisms for the public choice of priorities of the innovation process and their implementation and creating tools for broad information support and promotion of innovative ideas to create success stories.

The most effective tool for developing local communities is the involvement of people in joint activities aimed at achieving the public good or benefit for all participants. In these conditions, the main tasks of local community development practices are capacity building and community empowerment, the transformation of residents from actors into actors, 
development of participatory democracy and involvement of residents in the development of the territory (enhanced participation).

Today, nobody disputes that lifestyle as a subjective factor determines the state of health by $50-55 \%$ in current conditions. Then, by statistical weight is the impact of the environment (ecological situation), the impact of health is estimated at 20-25\%. The proportion of genetic, hereditary factors ranges from 15-20\%. However, health services and systems accounted for only $8-10 \%$ of public health. This distribution is now accepted by the WHO and is widely known as a formula (model) of health as a primary living condition [10].

One of the possible invariants of the structure of the human quality model is presented in the form of such interacting blocks [11]:

- personal systemic and social quality;

- personal value and worldview quality;

- personal spiritual and moral quality;

- personal psychological and motivational quality;

- personal quality of intellectual development;

- personal quality of human physical development.

These blocks of the inner quality of a person undergo their formation and development under the influence of 3 nested spheres: the sphere of the quality of personal knowledge, the sphere of the individual's activity, the sphere of the quality of the culture of the individual. Through these spheres, two main directions in educational training occur: the quality of general education training and the quality of professional training and the impact of the quality of education. The dialectic of this interaction is that knowledge affects the systemic and social quality and, as a part of it, the quality of professional training and all others, including the psychological and motivational block, blocks of intellectual and physical development. Knowledge is instrumentalized, passing into skills, professional competencies, professional qualification readiness for the corresponding professional and qualification activities [11].

Based on these directions of innovation, development at the local level should be distinguished based on the criterion of the leading orientation of the territory's economy under its position in the settlement system and the criterion of specific local conditions.

Accordingly, the innovation landscape can be considered a set of interdependent structures aimed at reproduction and commercialization of accumulated knowledge, which operate in a particular economic and social context of local innovation archetype.

The problem of innovation development in the local innovation archetype dimension has the following levels:

1) ability to generate new knowledge, which requires a high level of development of basic science;

2) ability to transform basic knowledge into applied research and development that can be demonstrated to business;

3) demand from business for new technology solutions;

4) institutional conditions that encourage the researcher to commercialize research results. 
As a result of the functioning of these levels, a certain level of innovation receptivity is formed, which can be defined as the ability of the economy to include in its structure and activities changes caused by the innovation process, which can be both external to the economy and development. In this case, the key issue of the analysis is innovation (technological) ability, which the authors define as the ability to use knowledge effectively, and social ability - the country's ability to make technological or organizational progress [12].

Technological and social capabilities are very dynamic, as they can be lost with longterm unclaimed and accumulate in case of actual need. In technological progress, there is an accumulation of technological knowledge, but real achievements are much more. After all, the essence of technology transfer is training. In addition to general and special knowledge, acquiring new knowledge (training ability) is acquired and increased. Thus, there is an accumulation of advantages: upon reaching a certain level of technological capability, assimilation and improvement of imported technologies are facilitated, which increases technological capability [13].

The author, in previous studies [14], proposed to consider the development resources definition in two dimensions:

1) set of economic and social resources, located in some territory (region), given the interchangeability and exchange value of the resources both within a given territory and in the external relations;

2) organizational and economic forms and processes of resource use, involved at present or have the potential for involvement in the development process in the future. So the author's definition of development resources includes resource definition in traditional and market sense and management efficiency issues.

Each subsystem of the economy (national or local) management should identify and analyse risks of anticipated threats to resource security, identify variants of responses and implement appropriate control actions. Given analysis and preparatory work should be maintained and updated as conditions are changing. This can be done according to six primary groups of development resources:

1) natural resources (land, minerals, fuels, climate; their quantity and quality);

2) human resources (labour supply and quality);

3) physical capital (machines, factories, roads; their quantity and quality);

4) technological factors that connect other resources;

5) institutional factors that include the banking system, the legal system, good health care etc.;

6) relationship capital and cooperation factors that include the process of resource interchangeability through partnerships.

Based on this classification, the problems of socio-economic development of small towns are the low level of development of the urban base, labour market and infrastructure, lack of sources of financial resources. The capacity of a large part of territorial communities and local self-government bodies of small towns to realize their capabilities and delegated powers is deficient, which leads to a low level of provision of relevant social and administrative services to the population. 
The chosen model of resource and innovation development should determine all the main aspects of innovation policy: the configuration of the supporting infrastructure, the main areas of investment, selection and support of priority investment projects, training programs and more. The authors note that the model of resource and innovation development can be most effectively implemented at the regional level. Thus, resource-innovation development does not involve reducing the potential of basic raw materials industries, but on the contrary, their development on an innovation basis and completing the structure of the economy through the development of service and related industries capable of providing the resource sector with modern equipment, new technologies and innovation services, processing of resources and extension of technological chains for product processing and development of other high-tech and knowledge-intensive industries that can compete in both domestic and foreign markets [15, p. 685].

Interaction with business as a practical implementation of innovation archetype should be organized with the help of a map of local values [16], which is a binary resource that can work by combining knowledge about the territory and local resources ("Listen to Earth") and local community ("Listen to People").

A 2012 study confirms the Global Innovation Barometer findings that companies go beyond the traditional, closed innovation model, working in a new system. This system allows to develop cooperation between multiple partners, use the creative resources of medium and small enterprises and individuals and thus create solutions that meet the needs of local markets. Business leaders worldwide believe that the most significant innovations in the $21^{\text {st }}$ century will be aimed not just at a profit but also at the development of society and meeting universal needs.

The map of local values is compiled to increase the territory's economic, social, and cultural capitalization and the local community. According to the local population and administration, it should reflect the assessment of the situation in the territory. It should become the basis of a strategy for self-development based on intersectoral cooperation (coordination of interests with other levels of government and business). To create such a map, it is necessary to formulate priorities (based on the assessment of the existing situation taking into account new threats and opportunities), main directions and indicators of development, which will identify real stakeholders and adequately assess the risks of losses and benefits for them from investment projects.

Based on the map of local values Identifying development priorities should take into account:

1. Prevention of risks of loss of values and resources from innovation and investment projects by ensuring a balance of three types of efficiency (budget, commercial and public).

2. Preservation of existing values with increasing their capitalization (social, cultural and economic) and identifying opportunities for the development of their potential on an innovation basis.

3. Restraining the impact of potentially inadequate for the production area with the loss of capitalization of values (for example, constructing a road or plant without considering the interests of local communities).

Consider examples of implementation of innovative development strategies. 
Omelyanenko V.A.

With the national innovation program's adoption in Canada, we can talk about the deepening regionalization of science. One of the main areas of innovation is developing the scientific and technological potential of individual communities and settlements (community level) [17].

The main idea of building trust capital is the principles voiced by Marko Begic, former mayor of Anchorage and senator from Alaska, who noted that he spent 50\% of his time communicating with business representatives when he was mayor. His main advice is that mayors should work with community-based entrepreneurs, learn about their business and build an atmosphere of mutual trust that will allow administrations to interact with the private sector to innovate and make the communities in which businesses are located competitive growth-oriented [18]. The main thing is to convince companies in the community to think about product quality or efficiency of production and operational processes and start looking for innovative solutions to these issues with the involvement of local resources.

Representatives of the commercial sector should also take part in the development of local communities. In the USA, for example, Community Development Financial Institutions, a new type of private financial institution that specializes in lending locally as part of local community development, have become widespread [19].

In Alberta, the Ministry of Innovation and Science was established in 1999, bringing together several provincial departments and initiating many innovation support programs. It is also crucial that the field of education in Canada falls within the competence of the provincial government; at the federal level, there is not even a Ministry of Education. The innovation program was adopted as part of a broad public discussion of tasks and mechanisms, and its implementation is based on attracting the potential of the general public from all regions. The country's government, adopting the program of creating an innovation society, assumed that the innovation process should involve all sectors of the economy and society, which in close cooperation and financial and informational support of the state can ensure innovation tasks.

Communities are increasingly becoming sources of new ideas about the directions in which public policy should be developed [20]. For example, the municipality of Boston (USA) has developed a special application for the iPhone, which provided a two-way communication channel for exchanging information with citizens. The implementation of such important projects as Reboot Britain has confirmed that using the Internet for crowdsourcing to empower citizens and governments is becoming a reality. In European countries, especially in the United Kingdom, there are also many examples of the involvement of citizens in public policy at the local level through projects such as Open City in Birmingham.

The considered provisions are relevant for applying the concept of place marketing (F. Kotler, C. Asplund, I. Rein, D. Haider [21]). In its context, we can mention specific examples of the tools for creating innovation landscapes in Canada, that include the following community initiatives:

- Collective private forest management: provides more efficient management and increased forest productivity. These initiatives are also responsible for reforestation to create new jobs in non-urban forest-dependent settlements. 
- Duchenne Reserve: organizes the management of the inhabitants of most of the state lands for recreation, tourism and nature protection with the creation of jobs.

- Agri-environmental agricultural clubs: 50 farmers came together and hired an agronomist to implement best practices to protect soils and natural resources. Measures to manage the economic development of small towns include:

- Cais popularises play an essential role in the history of non-urbanized regions of Quebec; these credit unions continue to play a significant role in the economic development of the non-urbanized sector and the economy of Quebec.

- Local Development Cooperatives: a new form of cooperative in which all citizens of one or more settlements participate in order for collective enterprises to develop activities that improve local socio-economic conditions.

- Local Development Agencies established by the federal development agency (known in other provinces as the Corporation for the Further Development of Human Settlements), in which management is delegated to local stakeholders who provide technical and financial support to newly established small businesses.

- Centre for Local Development (CLD): local government creates incentives for and promotes local economic development. Funds are provided by both the central government and local authorities.

- Local development funds: together with CLD and municipalities, these local investment funds help finance newly established small businesses.

These facts and examples necessitate an open, permanent, competitive and creative dialogue of business, academia, and community in innovation landscapes, which allows the exchange of ideas and technological solutions to identify the needs of society to use collective intelligence to create innovative services.

Conclusions. The formation of local innovation landscapes involves the choice of forms of innovation and interaction between government and business based on socio-cultural innovation archetypes. Based on the analysis, the study has found that innovation development at the local level is associated with strengthening the social orientation of innovation and the emergence of local innovation landscapes as an institutional basis of innovation development. Examples of implementation of initiatives that can be used in the formation of local innovation landscapes in the united territorial communities of Ukraine were identified. Local innovation archetype as a base of the local institutional system (formal and informal elements) focuses on innovative development, allowing new participants to innovate networks, including new social groups.

\section{References}

1. Temple, J. (2001). Growth Effects of Education and Social Capital in the OECD. In J.F. Helliwell (Ed.), The Contribution of Human and Social Capital to Sustained Economic Growth and Well-being: International Symposium Report, Human Resources Development Canada and OECD. https://doi.org/ 10.1787/eco_studies-v2001-art11-en

2. Galiullin, D.L. (2009). Social trust and social capital in regional development policy. PNU Bulletin, 2 (13), 221-228 [in Russian]

3. Hall, R., Jones, Ch. (1999). Why do Some Countries Produce So Much More Output Per Worker than Others? The Quarterly Journal of Economics, 114, 1, 83-116. https://doi.org/10.1162/003355399555954 
4. Bruno, J. (2012). A new paradigm of innovation in non-urbanized regions: learning based on the experience of the population and settlements of non-urbanized regions and in conjunction with them. OECD conference [in Russian]

5. Weber, G. (2002). Globalisierung und ländlicher Raum - eine spannungsgeladene Beziehung. Ländlicher Raum, 3, 3-14.

6. Simon, G. (2005). Hidden Champions. Lessons from the 500 best unknown companies in the world. Moscow: Business [in Russian]

7. Prokopenko, O., Omelyanenko, V. (Eds.). (2020). National Development Goals: Innovation Framework. London, United Kingdom: Agenda Publishing House Limited.

8. Omelyanenko, V. (2018). National strategic innovation security conceptualization. Technology audit and production reserves, 3 (5), 36-42. https://doi.org/10.15587/2312-8372.2018.134242

9. Omelyanenko, V. (2020). National strategic innovation security policy making (theoretical review). Tallinn: Teadmus.

10. Akopyan, A.S., Bushuev, V.V., Golubev, V.S. (2002). Ergodynamic model of man and human capital. Social sciences and modernity, 6, 98-106 [in Russian]

11. Subetto, A.I. (2003). The quality of life and the quality of education are the main accents of the national idea of Russia in the XXI century and the criteria of state policy. Academy of Trinitarianism. publ. 10854 [in Russian]

12. Shin, J.-S. (1996). The Economics of the Latecomers: Catching-up, Technology Transfer and Institutions in Germany, Japan and South Korea. London, New York: Routledge.

13. Balabanova, E.S., Grudzinsky, A.O., Kudryashov, Yu.G. (2002). Modernization of enterprises: factors and directions. Sociological research, 6, 18-19 [in Russian]

14. Omelyanenko, V.A., Kudrina, O.Y., Volodin, D.V. (2017). Conceptual principles of development resources security analysis. Marketing and Management of Innovations, 2, 280-287. http://doi.org/ 10.21272/mmi.2017.2-26

15. Nagaeva, O.S. (2018). Model of resource-innovative development of raw materials region. Journal of Innovation Economics, 8 (4), 679-694. https://doi.org/10.18334/vinec.8.4.39541 [in Russian]

16. Belogolovov, V.F. (2010). Methodological guide for public support of local community development projects. URL: http://ecodelo.org/2987-metodicheskoe_posobie_po_obshchestvennomu_ soprovozhdeniyu_proektov_razvitiya_mestnykh_soobshche [in Russian]

17. Sokolov, V.I. (2005). Canada: on the path of building innovation. USA. Canada: Economics-Politics-Culture: Scientific and Socio-Political Journal, 6, 23-36 [in Russian]

18. Atkinson, R. (2012). Innovation in Cities and Innovation by Cities. The Information Technology \& Innovation Foundation. https://doi.org/10.4337/9781781954058.00007

19. Krol, M. (2011). Development of local communities as a basis for improving the quality of life of people. Analytics. Social innovation laboratory. URL: http://cw.ru/analytics/3/view/13/ [in Russian]

20. Innovation policy for the future: EU innovation policy must support economic growth. (2011). Ernst \& Young. URL: https://docplayer.ru/75741489-Innovacionnaya-politika-budushchego.html [in Russian]

21. Kotler, F., Asplund, C., Rein, I., Haider, D. (2005). Marketing places. Attracting investments, enterprises, residents and tourists to cities, communes, regions and countries of Europe. St. Petersburg: Stockholm School of Economics in St. Petersburg [in Russian]

Received on 18.01.20 